$\underline{\text { Back To Hit List } \mid \text { | Issue Table of Contents }}$

Skip navigation.

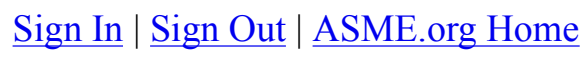

ASME Digital Library

ASMEDL.ORG » Advanced Search » Search Results

Adjust text size: 回国

- $\underline{\text { Home }}$

- $\underline{\text { Search }}$

- $\underline{\text { Journals }}$

- Applied Mechanics Reviews

- J. Applied Mechanics

$\circ$ J. Biomechanical Engineering

- J. Computational and Nonlinear Dynamics

$\circ \mathrm{J}$. Computing and Information Science in Engineering

- J. Dynamic Systems, Measurement and Control

- J. Electronic Packaging

- J. Energy Resources Technology

$\circ \mathrm{J}$. Engineering for Gas Turbines and Power

$\circ$ J. Eng. Materials and Technology

$\circ$ J. Fluids Engineering

- J. Fuel Cell Science and Technology

$\circ$ J. Heat Transfer

- J. Manufacturing Science and Engineering

- J. Mechanical Design

- J. Mechanisms Robotics

- J. Medical Devices

- $\mathrm{J}$. Micro and Nano-Manufacturing

$\circ \mathrm{J}$. Nanotechnology in Engineering and Medicine

$\circ$ J. Offshore Mechanics and Arctic Engineering

- J. Pressure Vessel Technology

- J. Solar Energy Engineering

J. Thermal Science and Engineering Applications

- J. Tribology

$\circ$ J. Turbomachinery

- J. Vibration and Acoustics

- Proceedings

- $\underline{\text { eBooks }}$

- Article Pack

Journal Info

- Purpose and Scope

- Masthead

- Citation Format

- Abstracted \& Indexed In

- Subscribe to Journal

- Announcements

- Call for Papers

- Authors Resources

- Submit Papers

Program Info

- $\underline{\text { Publications Committee }}$ 
- AMR Advisory Board

- Board of Editors

- Title History

- Permissions

- Contact Publishing Office

- Licenses

Services

- E-mail Alerts

- RSS Feed RSS

Scitation

- Scitation FAQ

- Scitation Home

- Scitation Search

- Search SPIN

- MyScitation

- Library Service Center

\section{Journal of Biomechanical Engineering}

J. Biomech. Eng. / Volume 113 / Issue 3 / RESEARCH PAPERS

\section{Convective Heat Transfer Coefficients in the Circulation}

J. Biomech. Eng. -- August 1991 -- Volume 113, Issue 3, 308 (6 pages) http://dx.doi.org/10.1115/1.2894889

ABSTRACT CITING ARTICLES
Author(s):
G. S. Barozzi and A. Dumas
Istituto di Fisica Tecnica, Facolta' di Ingegneria, Universita' di Bologna, Bologna, Italy
Convective heat transfer in the vessels of the circulatory system is
investigated numerically. In the modeling, account is taken of the
non-Newtonian rheological properties of blood and the presence of a
cell-depleted plasma layer at the vessel wall. The latter is found to produce
a remarkable enhancement of the heat transfer rate in the small vessels,
while the effects due to the rheological behavior of blood are comparatively
low. A comparison with experimental data available in the open literature is
finally attempted.

(C1991 The American Society of Mechanical Engineers

$\begin{array}{ll}\text { History: } & \begin{array}{l}\text { Received August 2, 1989; revised } \\ \text { March 15, 1991 }\end{array} \\ \begin{array}{l}\text { Digital Object } \\ \text { Identifier }\end{array} & \text { http://dx.doi.org/10.1115/1.2894889 }\end{array}$

Buy a full-text PDF (678 kB) of this Paper

(c) Connotea 回 CiteULike $\mathbf{m}$ del.icio.us $\mathbb{B}$ BibSonomy

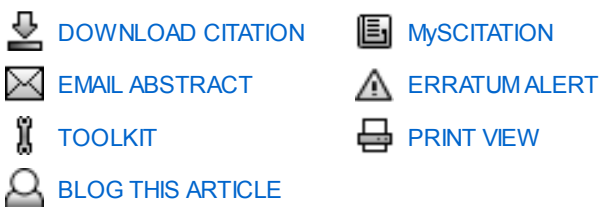

\section{PUBLICATION DATA}

Coden:

JBENDY

ISSN:

0148-0731 (print) 1528-8951 (online)

Publisher:

ASME 
$\underline{\text { Library Home }}|\underline{\text { Journals }}|$ Conference Proceedings $\mid$ E-Books

(C) 2012 ASME. All rights reserved. Privacy Statement $\mid$ Terms of Use $\mid$ Contact Us

The ASME Digital Library is hosted on the AIP Scitation platform.

$\underline{\text { Back To Hit List } \mid \text { | Issue Table of Contents }}$ 